\title{
Seasonal Variation of Waterbirds in the Periyakulam Lake, Tiruchirappalli, Tamil Nadu, Southern India
}

\author{
Sivanantham Mohanraj and Jeganathan Pandiyan
}

\section{ABSTRACT}

The data collected on the population characteristics of waterbirds. The data were collected from January 2011 to December 2013. Birds were counted using direct count method. During the study period of waterbirds belonged to 37 species and 31 genus, included under 14 families and 7 orders were recorded. Among the 37 species, 5 species were migratory, 17 species were resident, and 15 species were resident migratory. Among them 5 species are categorized as Near Threatened and the remaining 32 species are Least Consent as per the IUCN categories, (2021). Among the four seasons the post monsoon season attracted higher turnover (1036.1 \pm 243.01 No./ha.) of bird density than the other seasons recorded. The diversity was also highest during the post monsoon when compared to other seasons. But the waterbird species richness was higher during monsoon season than the post monsoon and other seasons. The density, diversity and waterbird species richness showed significant variations among the years $(\mathbf{P}<0.05)$.

Keywords: India, Periyakulam lake, Populations, Seasonal variation, waterbirds, Wetlands.
Published Online: January 24, 2022

ISSN: $2684-446 \mathrm{X}$

DOI :10.24018/ejgeo.2022.3.1.209

Sivanantham Mohanraj*

PG \& Research Department of Zoology, Government Arts College (Autonomous), Karur, Tamil Nadu, Southern India.

(e-mail: cormorantmohanraj@gmail.com) Jeganathan Pandiyan

PG \& Research Department of Zoology \& Wildlife Biology, A.V.C. College (Autonomous), Mannampandal, Mayiladuthurai, Tamil Nadu, Southern India.

*Corresponding Author

\section{INTRODUCTION}

The wetlands are the most productive and biologically diverse in the world but very fragile ecosystems [1]. The wetlands are among the most important ecosystems on earth. Wetlands also have been called "biological supermarket" because of the extensive food chain and rich biodiversity that they support [2]. Described that the wetlands are described as "kidney of the landscape" because they function as the downstream receivers of water and waste from both natural and human resources. Wetlands are the most productive and vital ecosystems of the world [3] and occupy about $6 \%$ of the earth's surface [4].

The term wetland refers to lowlands covered with shallow and sometimes temporary or intermittent waters. They are referred to by such names as marshes, swamps, bogs, wet meadows, potholes, sloughs, and river. Overflow lands, shallow, lakes, and ponds usually with emergent vegetation as a conspicuous feature are included in the definition. "Wetlands" have been defined as swamps and other damp areas of land but in common parlance the word is used interchangeably with "Lakes", which denotes a large body of water surrounded by land. However internationally accepted term of wetlands describes them (Ramsar convention) as "area of marsh, fen, peat land or water whether natural or artificial, permanent or temporary with water, that is static or flowing, fresh, brackish or salt including areas of marine water, the depth of which does not exceed six meters" [5]. Wetlands and waterbirds are inseparable elements and support a rich array of waterbird communities [6]. The wetlands are providing significant contribution to the aquatic species as substrate or shelter especially for waterbirds [7]-[9]. The conservation of waterbirds is one of the vital responsibilities of many pioneering naturalists and waterbird conservation has evolved around the world and have been involved in the establishment of international organizations such as IUCN. Waterbirds are known for their provisioning services like natural indicator for vertebrates and invertebrates as well as important component of wetland ecosystem. There are about 9000 species of birds in the World, out of which approximately $23 \%$ (310 of 1340) of the bird species found in India [10], which are known to be dependent on wetlands [11]. The birds' population is dwindling continuously for the last few decades and more than hundred species of birds have become either endemic or endangered [12]. The bird population characteristics include density, diversity, and species richness. While studying avifauna of wetlands, parameters such as species richness, density and diversity of bird populations are frequently used as indicators to determine the habitat quality [13]-[18]. Current study focuses on the water birds that are categorized based on their feeding habits. It is also very interesting because the population of different categories of birds varied significantly seasonally variation of density, diversity, and species richness of Periyakulam lake.

\section{STUDY AREA}

Periaykulam Lake $\left(10^{\circ} .78 \mathrm{~N} ; 78^{\circ} .77 \mathrm{E}\right)$ is located in the Koothapar Village of Thiruvarampur, Tiruchirapalli District, Tamil Nadu, Southern India. It covers an area of 74.085 ha. 
The major water source for this lake is Cauvery River via Uyyakondan canal. The water resource is largely used for agriculture and inland aquaculture. About 629.84 ha agricultural land is irrigated from this lake. Koothapar village on the east commanding to irrigation of wetlands of these villages and Nagavalli and Vengur village in Tiruchirapalli Taluk. It receives drainage water from its free basin of $0.86 \mathrm{~m}^{2}$. besides the surplus of four upper tanks and the 4 supply canals from the Uyyakondan channel through a sluice at its left bank about 1 mile from the Thiruverumbur Railway station. This wetland attracts thousands of water birds comprising of resident and migrant species. Major flora includes Eichhornia crassipes, Phragmites karka, Zizania latifolia, Cyanodon sp., Limnophila sp., Sagittaria sp., Saccharum latifolium, Erianthus pucerus, Erianthus ravennae, Leersia hexandra, and Cyperus rotundus.

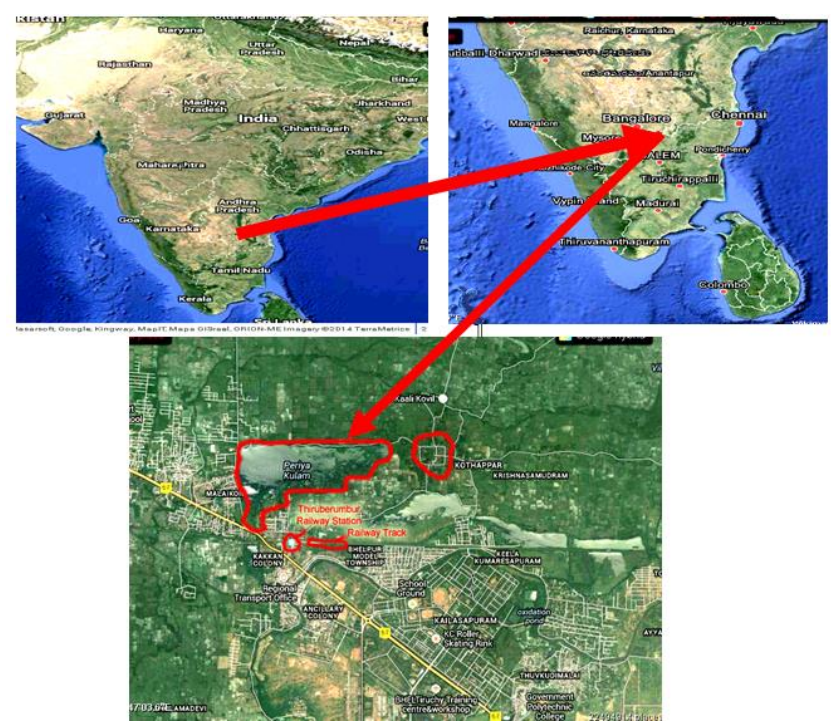

Fig. 1. Map shows the Koothapar Periyakulam Wetland, Tiruchirappalli District, Tamilnadu, Southern India.

\section{MethodOLOGY}

\section{A. Assessment of the Population of Waterbirds}

Birds were counted using direct count method [19]. For direct counting a suitable vantage point was selected, and all visible birds were counted. This method was very useful for counting the water birds. This counting was made without any bias and to ensure accuracy. 'Total count' method was followed for bird census wherever possible, and it was made walking round the wetlands or from specific vantage points [20]. Wherever the area was not completely covered, the percentage of coverage was marked. Systematic water birds count was carried out at different sites (three random sites were selected), each during January 2011 to December 2013. During counts, each site was divided into many sections in each section the birds were counted. All the birds on the ground or in the water were counted using binocular and any bird flying across the observer was also included in the counting. Birds flying behind the observer were not counted. Migratory, wintering, breeding/ summering and resident water birds were commonly encountered in the wetlands during the monsoon season [9].

\section{B. Density: Calculation of Bird Density}

The density of different ecological groups was calculated as number/hacter.

\section{Diversity}

Species diversity has two components i.e., the species richness in the community and species evenness or equitability [21]. The diversity was measured most directly as number of species and expressed as an index that incorporated the interplay of species richness and relative abundance of species into single value for the given community [22]. A number of indices have been used to calculate diversity.

\section{Species Richness}

Species richness was calculated using the number of species recorded in various habitat types. Species richness was measured by the number of water bird species recorded from different habitats of the wetland during monthly censuses [21]. The species richness was also enumerated for all ecological groups.

\section{RESUlt}

\section{A. Seasonal Variations}

Thirty seven species of birds were recorded only during the post monsoon season, which was comparatively higher than the other seasons studied during the study period (Table I). Besides, among the four seasons the post monsoon season attracted higher turnover (1036.1 \pm 243.01 No./ha.) of bird density than the other seasons recorded (Table I and Fig. 2), and during the monsoon season there was moderate density of waterbirds. The diversity was also highest during the post monsoon when compared to other seasons. But the waterbird species richness was higher during monsoon season than the post monsoon and other seasons (Table I and Fig. 3).

TABLE I: OVERALL SEASON WISE VARIATIONS OF CHARACTERISTICS OF BIRDS RECORDED FROM JANUARY 2011 TO DECEMBER 2013. (VALUES ARE

\begin{tabular}{cccccc}
\multicolumn{6}{c}{ MEAN \pm SE) } \\
\hline \multirow{2}{*}{$\begin{array}{c}\text { S. } \\
\text { No. }\end{array}$} & \begin{tabular}{c} 
Characteristics of Birds \\
\cline { 2 - 6 }
\end{tabular} & $\begin{array}{c}\text { Pre- } \\
\text { Monsoon }\end{array}$ & Monsoon & Post- Monsoon & Summer \\
\hline 1 & $\begin{array}{c}\text { Bird density } \\
\text { (No. /ha.) } \\
2\end{array}$ & $343.2 \pm 53.66$ & $957.9 \pm 123.28$ & $1036.1 \pm 243.01$ & $368.8 \pm 65.41$ \\
$\begin{array}{c}\text { Bird diversity } \\
\text { (H') }\end{array}$ & $0.01 \pm 0.001$ & $0.03 \pm 0.003$ & $0.03 \pm 0.005$ & $0.02 \pm 0.002$ \\
3 & $\begin{array}{c}\text { Bird richness } \\
\text { (No. of species) }\end{array}$ & $20.2 \pm 1.58$ & $21.2 \pm 0.94$ & $20.5 \pm 1.71$ & $14.8 \pm 0.97$ \\
\hline
\end{tabular}

\section{DISCUSSION}

Totally 37 species of waterbirds were recorded in the lake during the study periods from 2011 to 2013. Among the 37 species of waterbirds the Indian Little cormorant showed the higher density than the other species of waterbirds recorded in the lake during the study period especially monsoon and post monsoon seasons (Table I, Fig. 2 and 4). This could be due to fact that the lake prey provides hospitable parameter and act as a rich source of prey species to the water birds. The present investigation revealed that the prey for the 
waterbirds particularly fishes were assessed and showed higher density during the monsoon and post monsoon season. In addition to that nearby Periyakulam lake there is another wetland namely Ayyanar lake, which is one of the active breeding sites in the Indian little cormorant, but that lake size was very small in which the prey was also very less (unpublished data) when compared to this Periyakulam lake. Hence obviously, Indian little cormorant used the Periyakulam lake as a feeding ground and Ayyanar lake as a breeding ground and the distance between these two lakes is just $12 \mathrm{~km}$. Many studies reported that the abundance of Cormorant guild, showed seasonal variation, which is comprised of nomadic and sedentary resident species, which could be due to variations in food (fish) availability, water surface accessibility and breeding behaviour [23], [24]. Large number of Cormorants observed in the wet season coincided with the main breeding season of the guild [25].

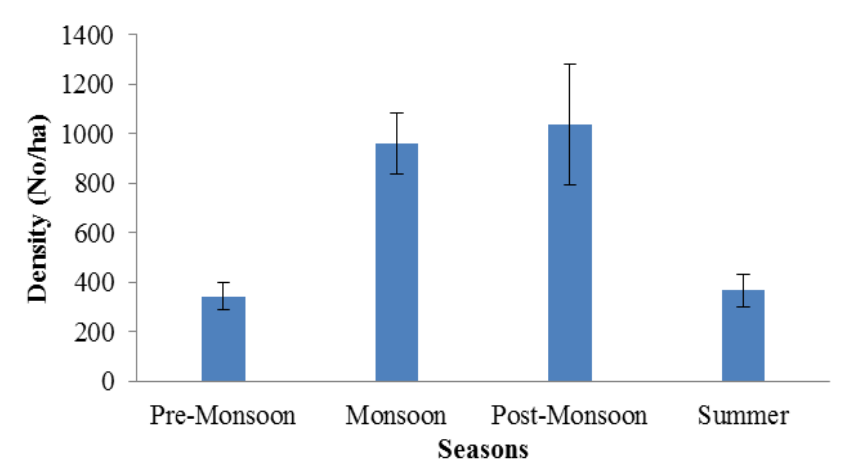

Fig. 2. Overall season wise density of birds recorded from January 2011 to December 2013. (Values are Mean $\pm \mathrm{SE})(\mathrm{N}=432)$.

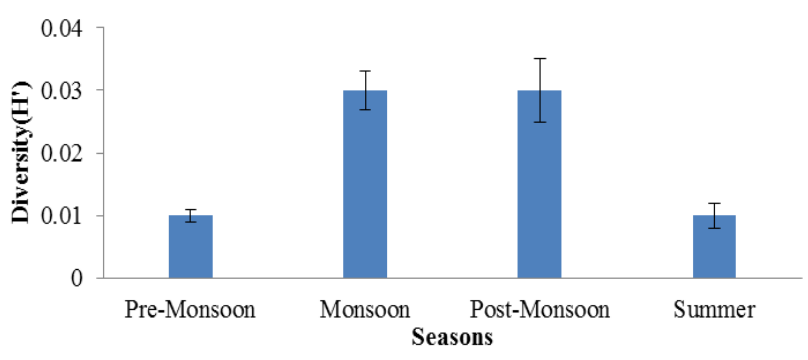

Fig. 3. Overall season wise diversity of birds recorded from January 2011 to December 2013. (Values are Mean $\pm \mathrm{SE})(\mathrm{N}=432)$.

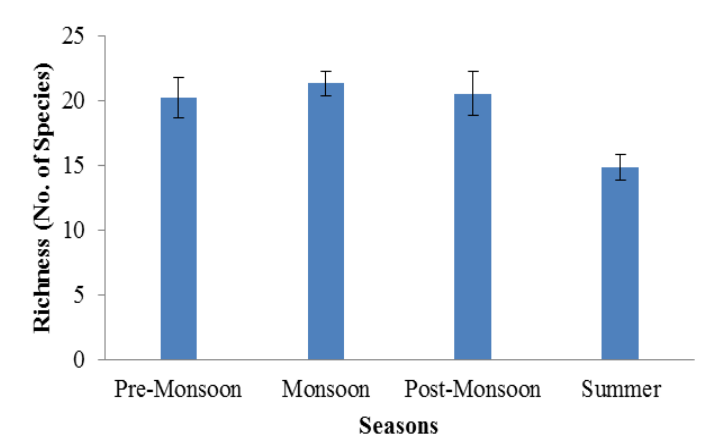

Fig. 4. Overall season wise species richness of birds recorded from January 2011 to December 2013. (Values are Mean $\pm \mathrm{SE})(\mathrm{N}=432)$.

It has been reported that the year, season, and months could influence the abundance and density of waterbirds, [26] stated that the waterbird population could show maximum density during the monsoon season (October to December) which compared to other seasons in the Pichavaram wetlands, India, and attributed to these seasonal parameters for the arrival of migrants from their breeding grounds as the reason. In addition to that the seasonal variations on waterbird population, abundance and diversity had been reported from other wetlands in different parts of India as well [7]-[9], [11], [19], [27]-[31]. This could be the major reason for the constant fluctuation of birds. Besides, no wetland provides water throughout the year other than this Periyakulam lake, except summer and which is also another reason for the stable bird density in the lake. According to the bird population is never entirely stable, even the seasonal fluctuations facilitated new births of the birds. In normal condition the variations from one year to another are always slight, but in exceptional circumstances, such as an unusual winter, produce considerable modification to the waterbird's populations. Seasonal variations in waterbird population, abundance and diversity had been reported for other wetlands in different parts of India [11], [28]-[32]. However, it has been reported that variations in abundance and diversity of water bird populations result from numerous and complex population processes and environmental events [33]-[35] including migration, breeding success, moulting regimes, seasons, floods, and droughts. The lake is the source of large-scale food supply to the water birds during monsoon and post monsoon season, but during the summer and pre monsoon? because fish catching, and other threats affect the availability of food species of water birds in the lake. Abundant food attracts large numbers of waterbirds and is important for the formation of waterbird colonies [36].

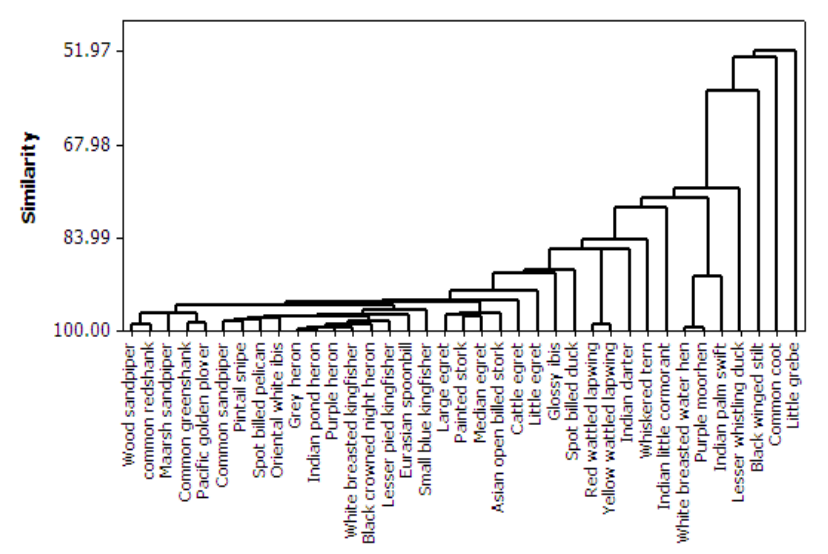

Fig. 5. Dendrogram showed the assemblage patterns of waterbirds recorded during Pre- monsoon in the Periyakulam Lake from January 2011 to December 2013.

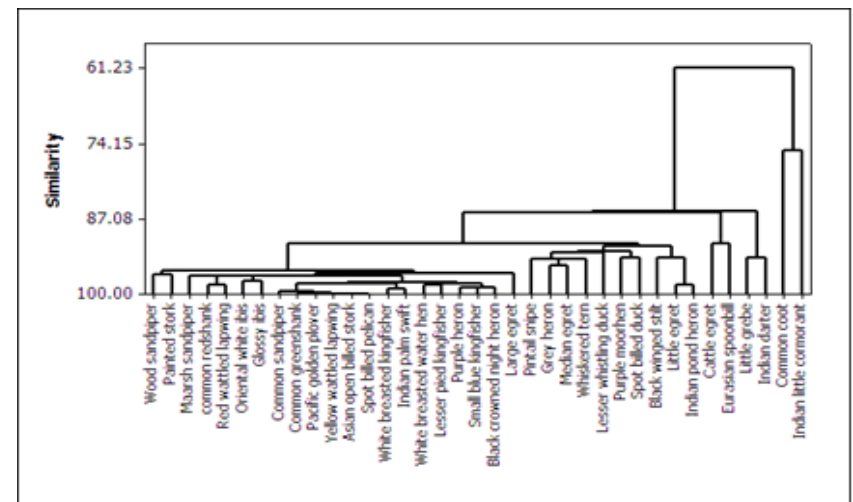

Fig. 6. Dendrogram showed the assemblage patterns of waterbirds recorded during Monsoon in the Periyakulam Lake from January 2011 to December 2013. 


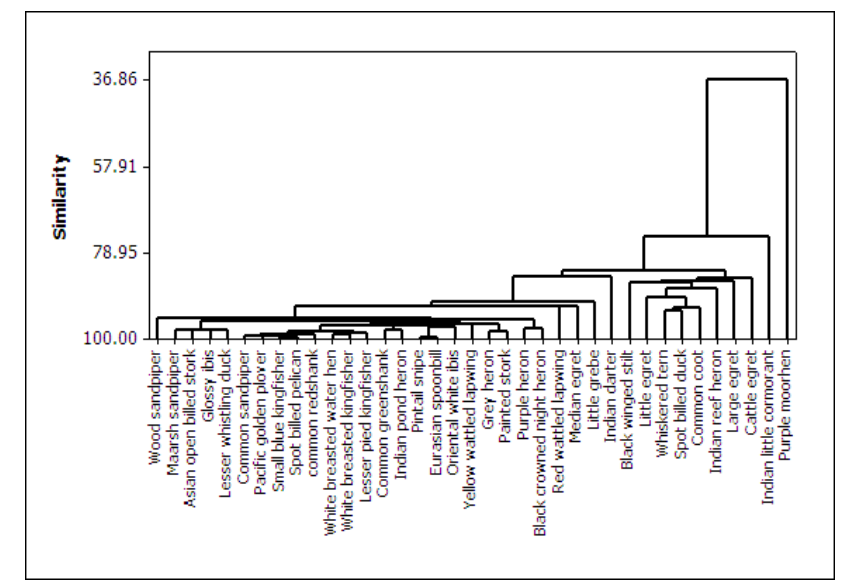

Fig. 7. Dendrogram showed the assemblage patterns of waterbirds recorded during Post- monsoon in the Periyakulam Lake from January 2011 to December 2013.

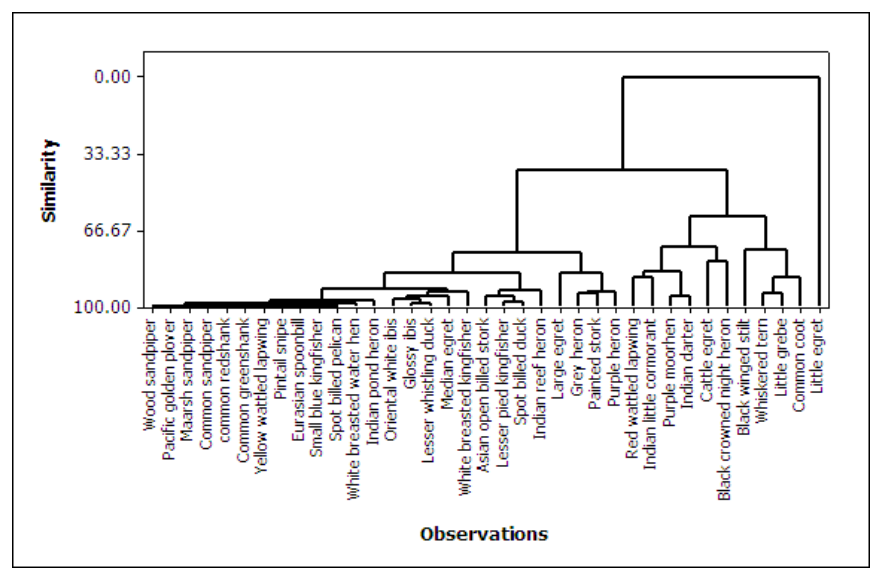

Fig. 8. Dendrogram showed the assemblage patterns of waterbirds recorded during summer in the Periyakulam Lake from January 2011 to December 2013.

\section{Cluster AnAlysis}

The cluster analysis was performed (non-parametric tests) to understand the birds assemblage pattern in relation to different seasons of the entire study periods in the lake. The results are represented in the dendrogrm (Fig. 5) 37 species of birds were grouped into two major groups in which the Little grebe formed one group and the other 36 species of birds were categorized into other groups during premonsoon season (Fig.6). During the monsoon season the Common coot and Indian little cormorant together formed one group and the remaining 35 species of birds were categorised into the other group (Fig. 7). Except the Indian little cormorant all other birds were grouped into one group. However, the remaining 36 species of birds were further assembled as two major groups during the post monsoon season (Fig. 8). The vertical and horizontal organization of the avian community with respect to habitat and other factors is essential to understand the bird assemblages. Various factors are combined to shape bird communities which include resource availability, vegetation structure, and abiotic factors like temperature, light, and precipitation [22], [37]. In the present study the 37 species of waterbirds are assembled in different groups at various seasons, which might be due to abundance of food or prey and their ability to access the resources in the lake. Species being adapted to particular foraging techniques have consequently led to varying breadths in foraging strata. The vertical distribution of foraging substrates may also cause species to have different strata breadths [38]. These assemblage patterns of the bird communities might be due to guild foraging strategies rather than the solitary foraging or feeding behavior of birds.

Conclusion: Recommendation to declare as Important Bird Area (IBA). This lake can be declared as one of the 'Important Bird Area'since this lake is supporting several waterbirds including migratory and resident birds. The lake is also attracting near threatened and vulnerable species of waterbirds. After intensive survey and study this lake can be declared as a Wildlife Bird Sanctuary in the future to conserve the endangered and vulnerable species of waterbirds visiting the lake.

\section{ACKNOWLEDGEMENTS}

We thank the Head of Department of Zoology and Wildlife Biology of AVC College (Autonomous) Mannampandal for providing necessary facilities and support during the study. We would like to express our gratitude to Tamil Nadu Forest Department (Tiruchirappalli) for permitting to logistic support to carry out this study period.

\section{REFERENCES}

[1] Gibbs J. P. The importance of small wetlands for the persistence of local populations of wetland-associated animals. 1993. Wetlands, 13: 25-31.

[2] Mitsch W. J. and Gosselink J. G. Wetlands 3rd Edition, John Wiley, 2000. New York.

[3] Maltby E. Waterlogged wealth. Why waste the world's wet places. 1986. London: Earthscan.

[4] Maltby E. and Turner R. E. Wetlands are not wastelands. Geographical Magazine, 1983. LV. 92-97.

[5] Chatrath K. J. S. Wetland of India. Ashish Publishing House, 1992. New Delhi.

[6] Grimmett R. and Inskipp T. Birds of Sourthern India. Om Books International, 2007.New Delhi, India.

[7] Mohanraj S. and Pandiyan J. Aerial foragers in the periyakulam lake, Tiruchirrappalli district, tamil nadu, southern india. International Journal of Pure and Applied Zoology, 2015. 3(3): 267-273.

[8] Mohanraj S. and Pandiyan J. Seasonal diversity of diving birds in the Periyakulam Lake, Tiruchirappalli, Tamil Nadu, India. Sci. Trans. Environ., 2015;8(3): 132-135.

[9] Mohanraj S. and Pandiyan J. Diversity of Large Waders in the Periyakulam Lake, Tiruchirappalli, Tamil Nadu, India. J. Sci. Trans. Environ. Technov., 2017;10 (3): 198-203.

[10] Murphy-Berman V., Berman J. Singh P. Pachauri A. and Kumar P. Factors affecting allocation to needy and meritorious recipients: A cross-cultural comparison. Journal of Personality and Social Psychology, 1984;46: 1267-1272.

[11] Hussain S. A., Mohapathra K. K. and Ali S. Avifauna profile of Chilka Lake. A case for conservation. Technical Report No.4. 1984. Bombay Natural History Society, Bombay.

[12] Shukla U. N. and Lone A. A. Water Birds of Sur Sarovar Bird Sanctuary Agra, Uttar Pradesh. Research Journal of Agricultural Sciences, 2010. 1(2): 135-139.

[13] Nilsson S.G. and Nilsson I. N. Breeding bird community densities and species richness in lakes. Oikos, 1978;31: 214.

[14] Weller M. M. Freshwater marshes and wildlife management. University of Minnesota Press. Minneapolis. As cited by Vijayan, L. 1995. Loc. 1981. Cit.

[15] Pandiyan J. and Asokan S. Abundance and Distribution of plovers, Pazhaiyar mudflat, Nagaipatinam district, southern India, $J$ Ecotoxicol. Environ. Monit., 2008a;18(2): 142-152.

[16] Pandiyan J. and Asokan S. Patterns of association and habitat use by migrating shorebirds on intertidal mudflats of Tirumullaivasal estuary, Nagaipatinam district, southern India, J. Ecotoxicol. Environ. Monit., 2008b;18(3): 259-265. 
[17] Pandiyan J., Naresh B. and Nagarajan R. Salt Pans-alternate foraging and roosting habitats for waterbirds. Proceedings of the Second International Conference on Indian Ornithology, pp. 57-59. Salim Ali Centre for Ornithoogy and Natural History, Coimbatore, 2013. India.

[18] Pandiyan J. Ecology of shorebirds in the tidal flats of Cauvery deltaic region of Southern India. Ph.D. Thesis, Bharathidasan University, 2002. Thiruchirappalli, India.

[19] Pandiyan J., Asokan S. Thiyagesan K. and Nagrajan R. Use of tidal flats in the Cauvery Delta region of SE India by shorebirds, gulls and terns. Wader Study Group Bull., 2006;109: 105-111.

[20] Nagarajan, R. and Thiyagesan, K. Waterbirds and substrate quality of the Pichavaram wetlands, southern India. Ibis, 1996;138: 710-721.

[21] Verner J. Assessment of counting techniques." Current ornithology. 1985. Springer US, 247-302.

[22] Wiens J. A. The ecology of bird communities. Volume 1. Foundations and patterns. Cambridge University Press, New York, 1989. USA.

[23] Guadagnin D. L., Schmitz-Peter A. Carvalho L. F. and Maltchik L. Spatial and temporal patterns of waterbird assemblages in fragmented wetlands of southern Brazil. 2005. Waterbirds, 28: 261-272.

[24] Hockey P. A. R., Dean W. R. J. and Ryan P. G. (eds). 2005. Roberts birds of southern Africa (7th edn). Cape Town: Trustees of the John Voelcker Bird Book Fund.

[25] Irwin M. P. S. The birds of Zimbabwe. Salisbury: 1981.Quest Publishing.

[26] Sampath K. and Krishnamurthy K. Birds of the Pichavaram mangroves and the adjoining coastal environs. J. Ecol. Soc., 1993;6: 2338.

[27] Ali A. and Ripley S. D. Hand book of the birds of India and Pakistan Vol. 1-12 Oxford University Press, 1980. Delhi.

[28] Ali S. Studies on the movement of population of Indian Avifauna. Ann.Rep. 1985-1986. Bombay Natural History Society, 1986 Bombay.

[29] Vijayan V. S. On conserving the fauna of Indian wetlands. Proc. Indian Acad. Sci. B. Suppl., 1986;91-101.

[30] Vijayan, V. S. Keoladeo National Park Ecology Study. Annual Report. 1987. Bombay. Natural, History. Society, 1988. Bombay.

[31] Sampath K. and Krishnamurthy K. Shorebirds of the salt ponds at Great Vedaranyam Salt Swamp. Stilt, 1989;15: 20-23.

[32] Sampath K. and Krishnamurthy K. Shorebirds of the salt ponds at the Great Vedaranyam Salt Swamps, Tamil Nadu, India. Stilt, 1989a;15: 20-23.

[33] Poulin B., Lefebvre G. McNeil R. Variation in bird abundances in tropical arid and semi-arid habitats. Ibis, 1993;135: 432-441.

[34] Romano M., Barberis I. Pagano F. and Maidagan J. Seasonal and inter-annual variation in waterbird abundance and species composition in the Melincue saline lake, Argentina. European Journal of Wildlife Research, 2005;51: 1-13.

[35] DuBowy P. J. Waterfowl communities and seasonal environments: temporal variability in interspecific competition. 1998. Ecology, 69: $1439-1453$.

[36] Bancroft C. T., Strong A. M. Sawicki R. J. Hoffman W. and Jewell S. D. Relationships among wading bird foraging patterns, colony locations, and hydrology in the Everglades. In: Davis SM, Ogden JC (eds) Everglades: The ecosystem and its restoration. 1994.St. Lucie, Delray Beach, 615-657.

[37] Cody M. X. (Ed.) Habitat selection in birds. Academic Press, Orlando, 1985. FL.

[38] Walther B. A. Grounded ground birds and surfing canopy birds: variation of foraging stratum breadth observed in Neotropical forest birds and tested with simulation models using boundary constraints. Auk, 2002b;119: 658-675.

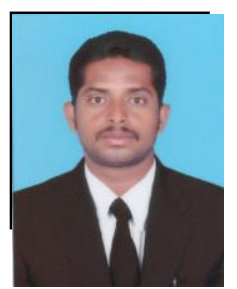

Dr. Sivanantham Mohanraj, Ph.D., Assistant Professor (Lecturer), Post Graduate and Research Department of Zoology, Government Arts College (Autonomous), Karur, Tamil Nadu, Southern India 639007 (Afield to Bharathidasan University). 